\title{
Dynamics of the Community in the Implementation of Complete Systematic Land Registration Program in the Land Office of Blora Regency
}

\begin{abstract}
Nuryanto $^{1}$ and Umar Ma'ruf ${ }^{2}$
Abstract: The birth of a complete systematic land registration program is expected to reduce the level of land problems faced by the government, especially in fulfilling land rights and accelerating the making of land certificates for the community. In this research, the formulation of $t$ he problem proposed is how is the dynamics of the community in implementing a complete systematic land registration in Blora Regency?. This study uses a sociological juridical approach to the type of analytical descriptive research. The data used for this study are primary and secondary data taken by library research methods, field research, and interviews. Based on the results of the study concluded that the dynamics of the community towards the implementation of the PTSL program by looking at the benefits of the program which has a great influence on the welfare of the community. In an effort to realize the welfare of the community, the community receiving land certificates through PTSL can be mobilized together to make various productive businesses that are expected to improve the community's economy.

Keywords: Community Dynamics; Complete Systematic Land Registration; Land Office.
\end{abstract}

\section{Introduction}

Land is an important economic factor and has strategic value from anywhere, social, political or cultural. ${ }^{3}$ Land cannot be separated from people's lives from the past until now. The human need for land is increasingly increasing, this is due to the increasing number of population which is getting higher, besides that land is a valuable asset owned by a country.

The Unitary State of the Republic of Indonesia based on the 1945 Constitution of the Republic of Indonesia Article 1 paragraph (3) states that "the State of Indonesia is a state of law" The state of law (constitutional) provides guarantees and provides protection for the rights of citizens, among others the right of citizens to obtain, possess and enjoy their property. ${ }^{4}$ With continuous and programmed efforts, development in the field of land is expected to be able to realize the conditions of land use and ownership that can bring prosperity and peace and security to the citizens of the community, nation and state. In accordance with the constitution of the State of Indonesia, namely the 1945 Constitution of the Republic of Indonesia in

\footnotetext{
${ }^{1}$ Student of Master of Law, Universitas Islam Sultan Agung Semarang and Civil servant, email: Nuryantosh68@gmail.com

${ }^{2}$ Lecturer of Faculty of Law, Sultan Agung Islamic University (UNISSULA), Semarang

${ }^{3}$ Urip Santoso, 2012, Hukum Agraria Komprehensif, Jakarta: Prenadamedia Group, p. 9

${ }^{4}$ Andrian Sutedi, 2016, Peralihan Hak Atas Tanah, Jakara: Sinar Grafika, p. 1.
} 
1945 Article 33 paragraph (3) which provides the foundation that "the earth and water and the natural resources contained therein are controlled by the state and used as much as possible for the people".

Land rights as one type of property rights, which are very important for the state, nation and people of Indonesia as an agrarian society that is building towards industrial development and so forth. ${ }^{5}$ In Indonesia it is the state that has a strong role in controlling land rights, with the state controlling the rights to state land to minimize land disputes. Land-related disputes are disputes that arise and concern the community in the rights to land owned by each individual that requires a legal certainty and guarantees for a land, thus the government needs to have an even distribution of development since the planning, implementation of data collection on a land, utilization to control until the process of land registration by the authorized government with simultaneous land registration.

In Indonesia, certificates of land rights act as strong evidence as affirmed in Article 19 paragraph 2 letter $c$ of the BAL and Article 32 paragraph 1 of Government Regulation Number 24 of 1997 . The study of the strength of the certificate is very important because first, the certificate provides certainty land ownership law so as to prevent land disputes. Second, with ownership of the certificate, the landowner can make any law as long as it does not conflict with the law, public order and morality. In addition, certificates have a high economic value when used as collateral for loans with mortgage rights on land. ${ }^{6}$

The few rights over ownership of land certificates in Indonesia can be seen from the government's target delivered through the official National Land Agency news. The Government through the Ministry of Agrarian Affairs and Spatial Planning / National Land Agency is targeting 5 million plots of land to be certified in 2017, then 7 million plots in 2018, 9 million plots in 2019 and 10 million plots in 2020. The acceleration of the legalization of assets is targeting around 63,193 .000 parcels of land, which will eventually realize all parcels of land have been certified by $2025 .^{7}$

Based on these problems, the government as the state organizer has the formal authority to set policies in an effort to overcome land disputes and accelerate the fulfillment of rights to land ownership in Indonesia. One of the efforts made is through government policy through the Ministry of Agrarian Affairs and Spatial Planning / National Land Agency by launching a National Priority program in the form of the Acceleration of Systematic Complete Land Registration (PTSL).

PTSL is a land registration process that is carried out simultaneously and includes all land registration objects that have not been registered in a village or kelurahan area.

\footnotetext{
${ }^{5}$ Ibid, p. 1

${ }^{6}$ I Ismail, 2017, Efektivitas Layanan Rakyat untuk Sertifikasi Tanah (LARASITA) di Kota Makassar, Jurnal Ilmiah Administrasita, Vol 8 (01), p. 6

${ }^{7}$ Bpn.Go.Id/News/News-Pertanahan/Default-66786, Kedaulatan Rakyat, Accessed on 10 November 2019.
} 
Through the PTSL program, the government guarantees legal certainty or land rights owned by the community. The purpose of the PTSL program is to accelerate the provision of legal certainty and legal protection of community land rights in a sure, simple, fast, smooth, safe, fair, equitable and open and accountable manner so as to improve the welfare and prosperity of the community and the country's economy, as well as reduce and prevent disputes and land conflict. ${ }^{8}$

This program is a ball pick-up service by visiting residents' homes online by utilizing the latest technology that is connected via satellite connected to the Land Office by utilizing internet facilities and wireless communication systems. However, based on the research conducted by the author, the socialization carried out by the Blora District Land Office to the community is still being maximally suppressed because the PTSL program is still untouched by the whole community in Blora Regency related to the program information due to various factors including the wide area of Blora Regency. Approach to the community as the main effort in carrying out a government policy. Can be seen from the reality that occurs in the field at this time the land assets that have been registered are relatively fewer than those that have been officially registered that have legal force. This has an impact on juridical implications such as the legal status of land titles that have not been certified.

Based on the description in the background of the problem above, the problem statement can be submitted: What is the dynamics of the community in implementing a complete systematic land registration in Blora Regency?

\section{Research Methods}

To conduct a study in this study the writer uses the sociological juridical method (social legal research) to study and discuss the problems raised. Juridical is an approach that uses legal principles and principles derived from written regulations ${ }^{9}$, sociological is an approach that aims to clarify the real conditions that exist and appear in the community to the problem under study or give importance to the steps of observation. ${ }^{10}$

This research is analytical descriptive, which reveals legislation relating to legal theories which are the object of research. To obtain data in this study, data collection methods such as library research, field research and interviews were used. Based on the nature of this study using descriptive analytical research methods, the data analysis used is a qualitative approach.

\section{Results and Discussion}

\footnotetext{
${ }^{8}$ Regulation of the Minister of Agrarian Affairs and Spatial Planning / Head of the National Land Agency of the Republic of Indonesia Number 6 of 2018 on Complete Systematic Land Registration.

${ }^{9}$ Soerjono Soekanto, 2008, Pengantar Penelitian Hukum, UI Press: Jakarta, p. 6

${ }^{10}$ Rony Hanitijo Soemitro, 1990, Metodologi Penelitian Hukum dan Jurimetri, Ghalia Indonesia, Jakarta, p. 34
} 


\subsection{Community Dynamics in the Implementation of Complete Systematic Land Registration in Blora Regency}

The mandate of Article 19 paragraph (3) of the LoGA states that land registration is carried out taking into account the state and community conditions, socio-economic traffic requirements and the possibility of its implementation according to the Minister of Agrarian's consideration. Besides land registration, distribution is also required land sources, production factors and a balanced (fair) economy so as to realize the prosperity of all walks of life in the framework of sustainable development. President Joko Widodo's era, land reform became a core part of agrarian reform, this program was stated explicitly in Nawacita as the 5th agenda in the 9 priorities of the Jokowi-JK leadership. In my opinion, the main challenge of land reform in Nawacita Jokowi-JK is to face the problem of sectoralization and contestation of state land tenure whose domination is dominated in 3 (three) sectors, namely forestry, plantations and mining. Through Complete Systematic Land Registration (PTSL), the ATR / BPN Ministry is targeting 126 million certified land parcels throughout Indonesia by 2025.

The land certification / asset legalization policy implemented by the Blora Regency land office is a small part of the agrarian reform process. Bearing in mind, the agrarian reform agenda that should be encouraged by the government before issuing the legalization of land assets / certification is to rearrange the unequal control, ownership and use of land to create bases of the people's productive strength and realize social justice as stipulated in Article 5 (1) TAP MPR NO : IX / MPR / 2001 On Agrarian Reform. We need to know that the implementation of agrarian reform is intended to improve the welfare of society. There are two schemes that can be carried out by the government in implementing land reform, namely asset reform and access reform. ${ }^{11}$

The Blora Regency Land Office is a Government agency that serves community activities in the making of Land Rights Certificates, Land Rights Transfers, Land Rights Certificate Imposition and other land service activities. The first application for land registration at the Blora Regency Land Office is 2,500 parcels per year, so it takes 40 years to complete the registration of the parcels. ${ }^{12}$

In this regard, Bayu Indarto explained that the Land Policy used by the Blora Regency Land Office is currently referring to the Minister of Agrarian and Spatial Planning / Head of the National Land Agency Number 6 of 2018 on the Acceleration of Systematic Land Registration Complete. Land certification through the Systematic Complete Land Registration (PTSL) program in 2019, Blora District Land Office has completed a target of 60,100 registered parcels (PBT) with 39,481 parcels of land that

\footnotetext{
${ }^{11}$ Results of an Interview with Bayu Indarto, S.Sit, MH, Head of Legal Relations Section, Blora Regency Land Office, on 9 January 2020

${ }^{12}$ Results of an Interview with Bayu Indarto, S.Sit, MH, Head of Legal Relations Section, Blora Regency Land Office, on 9 January 2020
} 
have been issued Land Rights Certificates (SHAT) out of 40,100 SHAT realization targets. The land certification program in Blora Regency is running in accordance with the set targets, although it is still a little difference from the realization of the targeted SHAT. ${ }^{13}$

One of the reasons why PTSL exists, is to accelerate land registration, so that land that is in Indonesian territory can be registered immediately. In its implementation, PTSL requires a very large role, not only from designated committees from the land office, but also the role of village officials, as well as the community itself. The community can collaborate, or support the implementation of PTSL activities that are taking place in their region.

Certificate of land rights in the view of Bayu Indarto as Head of Legal Relations Section of BPN Blora Regency, is evidence and securities that guarantee legal certainty regarding the status of ownership and control of land. On the other hand, people see certificates of land rights more than passports, travel documents that will deliver into the world that are so formal and will get a lot of convenience. There are at least seven goals of agrarian reform namely reducing inequality in land tenure and ownership, creating a source of prosperity and community welfare, improving and maintaining environmental quality, improving food security, resolving agrarian conflicts, improving community access to economic resources and to reducing poverty and creating jobs. . The aim to reduce poverty and create employment is a manifestation of the concept of a welfare state (welfarestate) as an ideal model of development focused on improving welfare through giving a more important role to the State in providing universal and comprehensive social services to its citizens. The state is present not in the form of state domination but rather a mandate to carry out its obligations in fulfilling the rights of citizens. ${ }^{14}$

In this case, according to the results of an interview with Sutarman as community leaders in the Blora Regency, the dynamics of the community towards the implementation of the PTSL program by looking at the benefits of the program have a great influence on the welfare of the community. ${ }^{15}$ In an effort to realize community welfare, the implications that can be felt by the people of Blora Regency, the function of the land certificate can be assessed based on the views of Bayu Indarto, namely:

- Land title certificates serve as a strong proof. This is the most important function as referred to in Article 19 paragraph (2) letter c of the BAL. A person or legal entity will easily prove himself / herself as the holder of rights to a parcel of land. If the name is clearly stated in the certificate. Based on the main function as a valid proof, the interest of Blora Regency people to register their land is increasing;

\footnotetext{
${ }^{13}$ Results of an Interview with Bayu Indarto, S.Sit, MH, Head of Legal Relations Section, Blora Regency Land Office, on 9 January 2020

${ }^{14}$ Results of an Interview with Bayu Indarto, S.Sit, $\mathrm{MH}$, Head of Legal Relations Section, Blora Regency Land Office, on 9 January 2020

${ }^{15}$ Results of an Interview with Sutarman, Community Leader in the Blora Regency, on January 9, 2019
} 
- The land rights certificate gives the bank / creditor the confidence to lend money to the owner. Thus, the holders of land rights will be easier to develop their businesses because the need for capital is easily obtained. Based on this second function, Blora Regency through the legalization of assets contributes to cheap credit access;

- For the government, the existence of a certificate of land rights is also very beneficial even though the use is mostly indirect. This land registration data will usually be needed by the government for planning development activities such as urban development, installation of irrigation pipes, telephone cables, collection of land and building taxes, and so forth.

The relationship between legal certainty and legal protection of land rights to improving the welfare of the community is as follows:

- Providing a sense of security so that it is more productive in working on the land;

- Provide motivation to utilize land more productively;

- Have access to capital through granting Mortgage Rights on land certificates.

In general, people who are in the weak economy are very difficult to improve their economic level. This is because in general there are still problems in capital, namely the absence of adequate guarantees such as certificates. Granting land certificates to the community through the PTSL program gives access to capital individually. ${ }^{16}$ On a broad scale, the number of certificate recipients through the PTSL program can accumulate large capital. This was followed up with the establishment of venture capital such as cooperatives so that the use of capital would be effective. Thus, the certificate through the PTSL program has greater benefits and the dynamics of the community in accepting the PTSL program is very prominent in the enthusiasm for participating in the program. ${ }^{17}$

PTSL benefits can be felt by the community after carrying out PTSL activities, with the benefits of which are the recognized legal boundaries between residential areas, agricultural land, public areas and land that are produced in stages, land disputes / encroachment are identified and handled (transparency of land use rights, resulting in data for better protection of natural resources, Providing added value to and utilization of spatial planning activities. ${ }^{18}$ One of the reasons why PTSL exists, is to accelerate land registration, so that land that is in Indonesian territory can be registered immediately. In its implementation, PTSL requires a very large role, not only from designated committees from the land office, but also the role of village officials, as well as the community itself. The community can collaborate with, or support the ongoing implementation of PTSL activities in their area.

\footnotetext{
${ }^{16}$ Results of an Interview with Sutarman, Community Leader in the Blora Regency, on January 9, 2019

${ }^{17}$ Results of an Interview with Sutarman, Community Leader in the Blora Regency, on January 9, 2019

${ }^{18}$ Results of an Interview with Bayu Indarto, S.Sit, MH, Head of Legal Relations Section, Blora Regency Land Office, on 9 January 2020
} 


\section{Closing}

\subsection{Conclusions}

In this case the dynamics of the community towards the implementation of the PTSL program by looking at the benefits of the program which has a great influence on the welfare of the community. In an effort to realize the welfare of the community, the community receiving land certificates through PTSL can be mobilized together to make various productive businesses that are expected to improve the community's economy. The land certificate from the PTSL program is the same as the result of sporadic land registration, which is the certificate of ownership. Certificate of Ownership can be encumbered as a condition for obtaining capital loans. The results of the acquisition of capital loans indicate that the PTSL program provides support to the community in the form of access to capital loans. The community receiving certificates from PTSL has the potential to be in the form of mental attitude and motivation to advance through business opportunities. Community self potential is a very important internal factor in the formation of community formation programs. Self potential if developed will be a community participation movement that plays a role in the progress of the program.

\subsection{Suggestions}

- The community needs to actively participate in preparing and completing the requirements as an applicant related to the completeness of the land registration file other than counseling and socialization at the village level conducted by the Land Office.

- Community empowerment programs are very important for communities receiving land certificates through the PTSL program. Further research is needed to determine the effectiveness of community empowerment programs in accordance with community economic characteristics and geographical conditions.

\section{References}

\section{Book}

[1] Andrian Sutedi, 2016, Peralihan Hak Atas Tanah, Jakarta: Sinar Grafika

[2] Rony Hanitijo Soemitro, 1990, Metodologi Penelitian Hukum dan Jurimetri, Ghalia Indonesia, Jakarta

[3] Soerjono Soekanto, 2008, Pengantar Penelitian Hukum, UI Press: Jakarta

[4] Urip Santoso, 2012, Hukum Agraria Komprehensif, Jakarta: Prenadamedia Group

\section{Regulations}

[1] The 1945 Constitution of the Republic of Indonesia 
[2] Act of the Republic of Indonesia Number 5 of 1960 on Basic Regulations on Agrarian Principles

[3] Regulation of the Minister of Agrarian Affairs and Spatial Planning / Head of the National Land Agency of the Republic of Indonesia Number 6 of 2018 on Complete Systematic Land Registration

\section{Journal}

[1] I Ismail, 2017, Efektivitas Layanan Rakyat untuk Sertifikasi Tanah (LARASITA) di Kota Makassar, Jurnal IImiah Administrasita, Vol 8 (01)

Internet media

[1] Bpn.Go.Id/Berita/Berita-Pertanahan/Default-66786, Kedaulatan Rakyat 